\title{
IMPROVING THE STUDENTS' READING COMPREHENSION BY USING PQ4R STRATEGY TO THE EIGHTH GRADE AT SMP NEGERI 2 PANCUR BATU
}

\author{
Sartika Margaret Br Rajagukguk, Karisma E. Tarigan, Fiber Yun A. Ginting \\ Catholic University of Saint Thomas \\ Email : karisma_tarigan@ust.ac.id
}

\begin{abstract}
Reading is one of the four language skills in English, they are listening, speaking, reading and writing. The students get bored in reading comprehension. Since they do not understand the text. Thus, they need some ways or strategy which could help students's reading comprehension on narrative text. The teacher should be creative to search for interesting strategy to teach reading comprehension on narrative text. PQ4R strategy can helps the students to understand on narrative text. The objectives of this study to find out the students' reading comprehension bu using PQ4R strategy. The subject of this study were the eight grade students of SMP 2 Negeri Pancur Batu. This research, the writer used Classroom Action Research (CAR) as the method of research. Tests were used to gather the quantitative data. Based on the finding of this study, it showed in pre-test only 4 students (11\%) who passed KKM ( the Mastery Minimum Criteria), and post test 25 students (71\%). The result of this research revealed that there was a significant improvement of the students' achievement from the pre-test to in the post test. This improvement was shown by the comparison between the mean score of pre-test $(51,2)$, and post test $(73,82)$. Furthermore, the students were interested in PQ4R strategy, it can be seen from the result of observation sheet and questionnaire. Therefore, PQ4R startegy was effective strategy in helping students to improve their reading comprehension especially in narrative text.
\end{abstract}

Keywords : PQ4R strategy, reading comprehension, narrative text

\section{INTRODUCTION}

Reading is one of the four language skills in English, they are listening, speaking, reading and writing. Reading with a purpose helps the reader to direct information towards a goal and focuses students' attention. Although the reasons for reading may vary, the primary purpose of reading is to understand the text. Reading is a thinking process, because it allows the reader to use what he or she may have already known, and it is also called prior knowledge.

Reading is needed to get the information or main idea from what the reader has read. The reader use knowledge, skills, and strategies to determine what the text meaning. So, reading is an important way in getting much information from the text. Cline et al. (2006:2), states that reading is decoding and understanding written

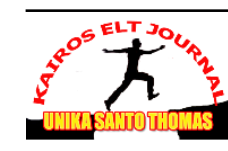


texts. Decoding requires translating the symbols of writing system (including Braille) into the spoken words which they represent. Understanding is determined by the purposes for reading, the context, the nature of the text, and the readers' strategies and knowledge. The readers must be able to translate the written words into meaningful language. The reading process will be more successful if it relates to students' interest, eagerness, ambition. Nowdays, teens tend to have interest in narrative text such as stories, legends, fable and fiction. It is proved from the stories that they focus on accident and how happened. Reading comprehension is the process of making meaning from the text. The goal therefore, is to again an overall understanding of what is described in the text rather than to obtain meaning from difficult words or sentences. According to Robert (2017:111) Reading comprehension is a complex interaction among automatic and strategic cognitive processes that enable the reader to create a mental representation of the text. Comprehension depends not only on characteristic of the reader, such as prior knowledge and working memory, but also on language processes, such as basic reading skills, decoding, vocabulary, sensivity to text structure, inferencing, and motivation.

Commonly, students get bored with reading and students feel reading is very difficult work because they do not understand how to comprehend a reading material. The teacher still focuses on learning teacher center style and the students just read the story by themselves and answer the question. One of strategies which can help students to understand reading text is Preview, Question, Read, Reflect, Recite, Review (PQ4R). Preview, Question, Read, Reflect, Recite, Review (PQ4R) strategy guides the students to understand reading based on the steps. The steps covers preview, question, read, recite, reflect and review. In each steps of PQ4R strategy the students can easily comprehend the text. Before directly reading of the text, firstly the students preview the text by looking at the tittle and heading of the text, in order to recall their prior knowledge.

Then, they need to form predicting question in order to make them easy to find the ideas in the text. Then, they also need to read the text completely to find the answer for the question before. This strategy also provides reflect in reading a text, because they need to memorize what they know about the text summarizing the text. Then, they need to recite aloud. And finally at the end of the steps they need to review make sure that all questions have been answered and the ideas in the text have been memorized

Based on the problem on the explanation above the writerchoose the title PQ4R strategy because this strategy can improve reading comprehension on students. The writer found that from interview with MrVictor as a teacher said that the students readingin SMP 2 PancurBatu were still low capability students in reading, the students not interest to read, it can be seen from students score, many students still got low score that is 60 , meanwhile the minimum mastery criteria is 70.

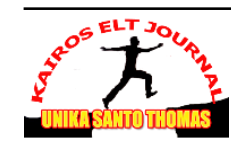


Based on the background of the study, the writer decides to conduct a research entitled Improving The Students' Reading Comprehension by using Preview, Question, Reading, Reflect, Recite, Review Strategy To The Eighth Grade Students of SMP Negeri 2 PancurBatu.

\section{LITERATURE REVIEW}

\subsection{Reading}

Reading is the process of extracting meaning from written text or printed text. It is assumed that the reader can comprehend and respond to what is read. The readers must be able to translate the writes words into meaningful langua ge. According to Negari et al. (2016:10) reading is a key skill for most of students in a foreign language and it should therefore take its place alongside the development of the other skills of languages: listening, speaking and writing. Reading process means not only "read" but tries to make interaction between the reader and text. It deals with how the readers can convey the meaning through the written symbols and process them into their mind.

Therefore Brown (2003:189) states that reading is processes of negotiating meaning, the reader are brought to the text a set of schemata for understanding it and intake is the product of that interaction.

According to Grabe and Stoller (2002:9) reading is the ability to draw meaning from the printed page and interpret this information appropriately. In other words, reading is the ability how to draw the meaning and interpret information appropriately. More definitions of reading that emphasize meaning indicate that reading is activated by print. The reader must be able to translate the written words into meaningful language. It is a complex knowledge, experiences, attitude and language community which is culturally and socially situated. The reading process requires continuous practice, development and refinement.

\subsection{Reading Comprehension}

Reading with comprehension means understanding what has been read. In addition, Westwood (2008:31) states that reading comprehension is an active thinking process through which a reader intentionally construct meaning to from deeper understanding of concepts and information presented in a text. From the definition, reading comprehension is the process of making meaning from the text to gain an overall understanding of what is described in the text. Readers may understand each word separately, but linking them together into meaningful ideas often does not happen as it should so they need to comprehend the text. Comprehension refers to the ability to go beyond the words, to understand the ideas and the relationship between ideas conveyed in a text.

Comprehension involves understanding the vocabulary seeing the relationship among words and concept, organizing idea, recognizing author's purpose, making judgment and evaluating. Pressley (in Al and Hameed, 2012:140) 
states that the development of comprehension skills is a long term developmental process which depends on language and text experiences from early stage of life. The more effortlessly students can recognize words, the more attention they can devote to comprehension.

According to Klingner, et al. (2007:2) reading comprehension is the process of constructing meaning by coordinating a number of complex processes that include word reading, word and world knowledge, and fluency. Based on the statements above reading comprehension is a way to understanding or comprehend of the text that includes not only word reading, world knowledge or fluency, but by reading comprehension we can get information and wide insight from the text.

\subsubsection{Level of Reading Comprehension}

Reading has different level of comprehension. Burns (1984:177) states that level of comprehension is divided into four levels. The following levels of comprehension tell about how far the students understand about reading material and which level that has been achieved.

\section{Literal Comprehension}

Literal comprehension is refers to the ability to understand what is stated by the writer taking the idea and factors that are directly stated on the printed page. The reader could easy go back in the underline the information desired. In this level, the reader know the words meaning, able to paraphrase or recall of details in directly in own words. The literal level is the easiest level of reading comprehension because a reader is not required to go beyond what that actually said.

\section{Inferential Comprehension}

Inferential comprehension refers to the ability to go beyond what is stated directly, to understand what the writer means by looking for the inside meaning. It can be said that inferential comprehension is the ability to get inference or implied meaning from the text. Skill for inferential comprehension include main ideas, cause effect relationship, references of pronouns and adverbs, admitted words, identifying words, authors purpose, predicting, ending, and drawing conclusion.

\section{Critical Comprehension}

Critical comprehension refers to ability to make analysis, evaluation, judgments and personal reacting about the ideas of information that writers offer in a passage. In critical reading, readers evaluate written material; compare the ideas found in the material with his/her previous knowledge and draw conclusion appropriately.

\section{Creative Comprehension}

Creative comprehension refers to ability of reader to use his/her imagination when reading the passage. Skills for creative reading comprehension include understanding cause-effect relationship on a story solving problem producing that creations. 
From the explanation above, it is clear that comprehension and reading are regarded as one activity, which can not be separated and it is program depends on the progress of the activity of mind. In other words, reading comprehension is an activity to grasp the meaning of written materials with full-meaning.

\subsubsection{Teaching Reading Comprehension}

Allen (2008:13) states that PQ4R strategy is enhance learner's ability to think deeply about content. Before reading, students actively preview the material , and from this generate questions they have about content. Thus they establish their own purposes for reading which leads to higher levels of comprehension.

\begin{tabular}{|c|c|}
\hline \multicolumn{2}{|c|}{ PREVIEW, QUESTION, READ, REFLECT, RECITE, REVIEW (PQ4R) } \\
\hline PREVIEW & $\begin{array}{l}\text { Preview the text by looking at the title, visual, headings, } \\
\text { subheadings. Look at how the material is organized and get a } \\
\text { general idea of the content. }\end{array}$ \\
\hline QUESTION & $\begin{array}{l}\text { Form some questions you have about the content based on the } \\
\text { information you gained during your preview. }\end{array}$ \\
\hline READ & $\begin{array}{l}\text { Read the material and try to answer the questions you generated } \\
\text { prior to reading. }\end{array}$ \\
\hline REFLECT & $\begin{array}{l}\text { Think about what you just read by making connection and } \\
\text { applying the information. }\end{array}$ \\
\hline RECITE & $\begin{array}{l}\text { Commit the information to memory by stating the mains point } \\
\text { aloud. You could use of the headings bold words, or visual to } \\
\text { make statements or generate questions. Add to your statements } \\
\text { of answer your questions to help put the information into your } \\
\text { long term memory. }\end{array}$ \\
\hline REVIEW & $\begin{array}{l}\text { Review the material by generating and answering questions } \\
\text { about the material you have read. }\end{array}$ \\
\hline
\end{tabular}

In addition, Welsch et al. (2005:242) states that the PQ4R method involves modelling, guided practice and cooperative implementation of reading process occur sequentially, predicting, questioning, visualizing. It should be praised for its masterful use scaffolding to get students thinking about underlying processes of reading. According to Slavin (in Brunner, 2013:93) PQ4R strategy is to provide students with a structure for reading difficult and challenging text. This strategy includes activation of prior knowledge through surveying text as well as questioning and setting purpose of reading. 
Based on the explain it can be concluded that teaching reading by using PQ4R strategy the learner's ability deeply about the content and guided the students implemetation the process reading occur and then to provide the students with a structure for reading difficultand challenging the text includes the prior knowledge.

\subsubsection{Genre Text}

According to Larson (1984: 365-366) genre can be defined thirteen genres of the text namely: spoof, recount, narrative, procedure, anecdote, hortatory, explanation, description, discussion, analytical, news item, report, and review.

\subsubsection{Narrative Text}

Narrative text is the text tells something imaginative or something that is just fantasy and the goal is only to entertain the reader. Anderson and Anderson (1997:8) states that Narrative text is a piece of text which tell a story and in doing so entertain and inform the reader or listener. Meanwhile, (in Permanaand Zahri, 2013:2) states that narrative text is a type of essay that tells a story or a series of event in which they occur. Ayres (2008:5) states that narrative text is one of the forms of developing writing, for example characters told the history of something based on thedevelopment of writing from the time to time.

Siahaan and Shinoda (2008:73) states that narrative is any written English text in which the writer wants to amuse, entertain people and deal with actual or vicarious experience in different ways. Narrative is a text containing a five components there are orientation, evaluation, complication, resolution and reorientation by which the writer amuses, entertain people, and to deal with actual or vicarious experience.

1) The orientation is beginning of the text. Its function is to set the scene and introduces the participants.

2) Evaluation. It is a stepping back to evaluate the plight.

3) Complication. This is the place in which a crisis arises.

4) Resolution in which the crisis is resolved for better or for worse. The fifth reorientation .it can be optional.

Gerot and Peter (1995: 204) states that the social function of narrative text are to amuse, entertain and deal with actual and vicarious experience. The generic structures of this text is orientation, evaluation, complication, resolution and reorientation. Narrative text focuses on specific and usually individualized participants. It also uses material processes, relational and mental processes. It also uses temporal conjunctions and temporal circumtances. It always applies past tense in the narration.

Bonner (1994:48) states that narrative text which context about a story like a story of citizen (folktale), the story of animals (fable), legend, etc. That a narrative 
text contain story by presenting the sequence of events and actors which are characteristic as heroes or cowards.

Based on the statement above, it is concluded that narrative is a text which contain a story ordered chronologically thatis orientation, evaluation, complication, resolution and re-orientation. Narrative is spoken written text to communicate a massage, which is used to interpret it is meaning in the story and to entertain the readers.

\subsection{PQ4R}

According to Allen (2008:13) PQ4R is an acronym for a comprehension and study strategy (Slavin) and variation of familiar SQ3R (Robinson). SQ3R represents five cognitive stages: survey, question, read, recite, and review. SQ3R is widely considered to be first printed, systematic method for reading a textbook. PQ4R is a variation of SQ3R the acronym represent six cognitive stages: preview, question, read, reflect, recite, and review. these system provide a strategy for students to approach organize, read, consider, and remember information.

In addition, Bower (1975:4) states that PQ4R is method involves the following activities in which a reader is encouraged to engage, preview, make up questions, read the text, reflect upon it, recite it and review it. The PQ4R method stimulates students actively engage the subject matter students are encourage to become proactive rather than reactive.

According to Anderson, Thomas \& Robinson (in Harley,2008:390) PQ4R is method emphasizes identifying the key points of what you are reading and adopting an active approach to the materials.

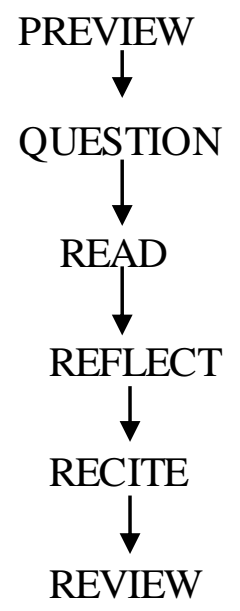

Figure 1. PQ4R method, Anderson, Thomas \& Robinson (in Harley, 2008:390)

Furthermore Ahuja (2007:40) states that PQ4R is a package of techniques that should be effective in improving the reading of chapter-long material when the students purpose is a through understanding of the content it.

Based on above that PQ4R is to engage the students to remember information and become proactive rather than reactive, and should be effective in 
improving the reading of chapter length material. The student purpose is a through understanding of content it. PQ4R represent six cognitive; preview, question, read, reflect, recite, review.

\subsection{The advantages of PQ4R Strategy}

According to Allen (2008:13) there are some advantages of PQ4R strategy such as:

1. It helps to make individual to know what to learn. It focuses student's attention, increasing interest, relating new ideas to previously known concepts and building comprehension.

2. The students are encouraged to actively interact with the material while reading by the following organizing techniques.

3. PQ4R is easy to use and can be applied to readings in most academic.

In addition, Brunner (2013:94) states that the advantages of PQ4R strategy are: provides structure for the students when reading difficult and challenging material, gives a specific purpose for reading, facilitates a deeper understanding of the text based upon interpretation, actively engages readers in the reading process, provides for reading, recitation, and written work.

Furthermore Rathus (2011:33) states that the advantages of PQ4R method is more that the standard built-in study guide. It goes well beyond a few pages of questions and exercises that are found at the ends of the chapter of many textbooks. It is an integral part of every chapter. It flows throughtout every chapter. It begins and end every chapter, and it accompanies the students page by page.

Based on explanation above can be conclude that the advantages PQ4R to make students to understanding the text easily and clear enough. It also help them to process and retain information on current event, especially for materials that are more difficult and helps the students to concentrate longer.

\subsection{Procedures of Teaching Using PQ4R Strategy}

In addition, Allen (2008:13) states that there are six procedures in PQ4R as follow:

1) Preview, the text by looking at the title, visual, headings, subheadings. Look at how the material is organized and get a general idea of the content. 2) Question, form some questions you have about the content based on the information you gained during your preview. 3) Read, the material and try to answer the questions you generated prior to reading. 4) Reflect, think about what you just read by making connection and applying the information. 5) Recite,commit the information to memory by starting the mains point aloud. The students could use of the headings bold words, or visual to make statements or generate questions. Add to your statements of answer your questions to help put the information into your long term memory. 6) Review, the material by generating and answering questions about the material you have read.

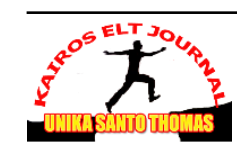




\subsection{Previous Researches}

The first, research had been conducted by Syafirah (2015) on his thesis entitled" THE APPLICATION OF PQ4R TO IMPROVE STUDENT'S READING COMPREHENSION". It stated that the result of this research showed and improvement of student's reading comprehension by using PQ4R strategy. It could be seen from the mean score of post-test was higher than score in pre-test. In cycle I was 62,2 and the score of pre-test in cycle II was 55,14. Furthermore, in cycle II, score in pre-test was 70,8 and score in post-test was 84,6 . It means that the using of PQ4R strategy can improve the student's reading comprehension.

The second research had been conducted by Manalu (2014) in his thesis entitled" IMPROVING STUDENTS ACHIEVEMENT IN READING COMPREHENSION THROUGH PREVIEW, QUESTION, READ, REFLECT, RECITE, REVIEW (PQ4R) TECHNIQUE. It stated that the result of the research showed and improvement of students achievement on reading comprehension through PQ4R technique. It could be seen from the mean score of post-test whic higher than score in pre-test. In cycle I, was 53,62 and score of pre-test in cycle II was 73,8 pos-test. The conclusion is that PQ4R can improve the student's achievement in reading narrative text.

\section{RESEARCHMETHOD}

\subsection{Research Design}

This research design is Classroom Action Research (CAR). Quantitative research is use to quantify the problem by way generating numerical data or data can be transformed into useable statistic. Quantitative data uses measurable data to formulate facts and uncover pattern in study. Quantitative data are obtained from students' pre-test and post-test. In this data collection, the researcher needs a collaborator. A collaborator in classroom action research is person who helps the researcher to collect the data.

The writer uses the Classroom Action Research by Burns (2010:2) states that Classroom action research is a part of a broad movement that has been going on ineducation generally for some time.

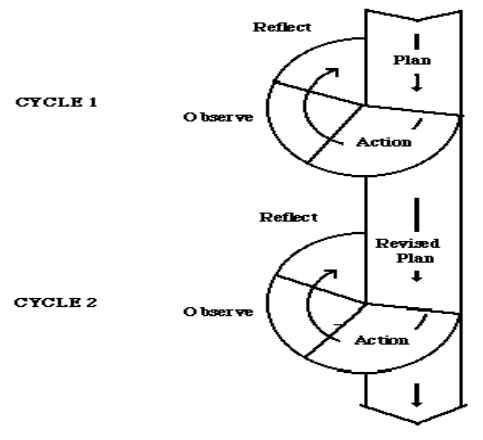

Fig 2. Classroom Action Research (CAR) Design by Kemmis\&Mc Taggart(in Burns, 2010:9) 


\subsection{The Place and Time of the Study}

The study will be conducted at SMP Negeri 2 Pancur Batu which is located at Jl. Jamin Ginting NO 21 Pancur Batu. There are two reasons why the writer chooses the school as the location of the research. They are: 1) Based on the preliminary research that was done by the writer, it is needed to improve the reading comprehension of the eighth grade students of SMP Negeri 2 Pancur Batu in the Academic Year of 2017/2018 using PQ4R strategy. 2) Based on the writer's knowledge there has never been any research about improving students' reading comprehension by using PQ4R strategy. This research will be conducted in July 2017.

\subsection{The Subject of the Study}

The subject of the research is the eighth grade students of SMP Negeri2 Pancur Batu in the Academic Year of 2017/2018. There five classes of the eighth grade students which consist of class $A, B, C, D, E$ the write chooses class $A$ as the sample of this study which consist of 35 students, consisting of 25 female students and 10 male students.

\subsection{The Source of Data}

The source of the data in this research is from what the writer gets during the research. The data of this research are qualitative data and quantitative data. Qualitative data are obtained from the observation teacher and students. Quantitative data are obtained from the students' reading test before, during and after the learning teaching process. In this data collection, the writer needs a collaborator. A collaborator in classroom action research is person who helps the writer to collect the data. The collaborator in this research is the teacher of Englis $h$ at the eighth grade students of SMP Negeri 2 Pancur Batu in the Academic Year of $2017 / 2018$.

\subsection{The Procedures of Classroom Action Research}

The writer uses Classroom Action Research (CAR) in conducting the research. The Classroom Action Research (CAR) model used by the writer is developed by Kemmis and Mc. Taggart. This Classroom Action Research (CAR) is arranged into two cycles. They are cycle one and cycle two. Kemmis and McTaggart in Burns (2010:7) state that action research typically involves four broad phases in a cycle of research. The four phases in a cycle are: (1) planning, (2) action, (3) observation, and (4) reflection.

\subsection{Techniques of Data Analysis}

The writer will apply the following formula to compute the students' score in order to measure the success of the learning teaching process. 
Students'score $=\frac{\text { Achievementscore }}{\text { MaximumScore }(100)} \times 100$

To know the mean of the students' score for each cycle, the writer applies the formula by Best and Kahn (2002:280) as follows:

Where:

$$
\bar{X}=\frac{\sum \mathrm{X}}{\mathrm{N}} \mathrm{X} 100 \%
$$

$\bar{X}=$ The mean of the students' score

$\Sigma \mathrm{x}=$ The total score of the students

$\mathrm{N}=$ The number of the students

The categorize the number of students who pass the test successfully, the writer applies the following formula:

$$
\mathrm{P}=\frac{\mathrm{R}}{\mathrm{T}} \mathrm{X} 100 \%
$$

Where:

$\mathrm{P}=$ percentage of students who get the point $\geq 70$

$\mathrm{R}=$ the number of the students who get point $\geq 70$

$\mathrm{T}=$ the total number of students who do the test

\section{DATA ANALYSIS AND DISCUSSIONS}

\subsection{The Data Analysis}

In the data analysis, there two types of data which are analysed to find out the result of improving students' reading comprehension by using Preview, Question, Read, Reflect, Recite, Review (PQ4R) strategy. The data analysis of this study are quantitative data, and quantitative data.

\subsection{Discussions}

The result of the teaching reading comprehension on narrative text by using PQ4R strategy could improved the students' reading comprehension on narrative text. PQ4R strategy was one of strategies that could make the students easier to learnt especially in reading comprehension. By applying PQ4R strategy on narrative text kept increasing from the pre-test until post-test. It was proved by the data which showed that the mean of the students' score in post-test $(73,82)$ was higher than the formative test $(64,17)$ and also higher than pre-test $(52,1)$. Thus, the percentage of the students improvement score from the pre-test to post-test $(44,17 \%)$ and from pre-test to formative test is $(12,9 \%)$. Preview, Question, Read, Reflect, Recite, Review (PQ4R) strategy helped the students to understand the material of narrative text easily because they were asked to generate their ideas during learning process. The writer and the English teacher decided the application of PQ4R strategy in teaching learning process is very helpful both to the students and the teacher. This media could help the teacher to find out the solutions of the students' problem especially in reading. From the questionnaires, can be seen the students response, for (students interest) 20 students (57\%) agree and 13 students (37\%) strongly agree, it means that they are interested to PQ4R strategy which was

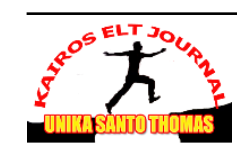


used in learning teaching process. The using of PQ4R strategy and students motivation, the students' response is 23 students (65\%) agree and 10 students (28\%) strongly agree, it means that they understand learning and students' motivation during teaching learning with PQ4R strategy. The students' response for ( the students' chance in asking) highest response is 15 students (42\%) agree and 28 students $(51 \%)$ strongly agree, it means that they choose because the students have a chance asking what they do not understand during learning teaching process, and for (the appropriateness) the students' response is 19 students (54\%) agree and 15 students (42\%) strongly agree, it means that PQ4R strategy can appropriates the students' reading comprehension on narrative text during teaching process.

From the field notes, the writer saw that the students actively prticipated in learning teaching processs and the result observation sheet, the PQ4R strategy made the students easier to understand the meaning from the text. It can be concluded that the students are enthusiatic in learning since they showed full attention during the learning teaching process. The colaborator also pprecitaed the writer executing the learning teaching process.

\section{CONCLUSIONS AND SUGGESTIONS}

\subsection{Conclusions}

After anaysing and discussing the data on previous research, then it can be concluded as follows:

1. Improving students' reading comprehension by using PQ4R strategy was effective espescially in SMP 2 Negeri 2 Pancur Batu. After analysing the data, on the previous chapter it is found that the students' reading comprehension improved from the pre-test into post-test.It means that there was an improvement toward students' reading comprehension by using PQ4R strategy. It was shown from the improvement of the mean of the students' score in pre-test was 51,2 and post-test was 73,82 . It can be stated that the score continuosly improved from pre-test to post test. Therefore, it could be concluded that PQ4R strategy can improve students' reading comprehension. Besides, the mean score, there was percentage of the students who got score above 70 . In the pre-test was 4 students $(11 \%)$ and post-test was 25 students (71\%). It means that there was an improvement of the students in their reading comprehension about (60\%) compared with the pre-test and post-test.

2. The students' responses in teaching reading comprehension on narrative text are categorized effective. It can be seen from the table that the students questionnaires in learning teaching process using PQ4R strategy, for (students interest) 20 students (57\%) agree and 13 students (37\%) strongly agree, it means that they are interested to PQ4R strategy which was used in learning teaching process. The using of $\mathrm{PQ} 4 \mathrm{R}$ strategy and students motivation, the students' response is 23 students (65\%) agree and 10 students (28\%) strongly agree, it means that they understand learning and students' motivation during 
teaching learning with PQ4R strategy. The students' response for ( the students' chance in asking) highest response is 15 students (42\%) agree and 28 students $(51 \%)$ strongly agree, it means that they choose because the students have a chance asking what they do not understand during learning teaching process, and for (the appropriateness) the students' response is 19 students (54\%) agree and 15 students (42\%) strongly agree, it means that PQ4R strategy can appropriates the students' reading comprehension on narrative text during teaching process.

\subsection{Suggestions}

Based on the research result, the writer gives some suggestion as follows:

1. For the English teacher, is better to use PQ4R strategy in teaching reading comprehension. PQ4R strategy effective to be implemented in the teaching reading comprehension during teaching learning process. The steps of PQ4R strategy as namely: Preview, in this steps the teacher gave the title of the text and general idea of the text. Question, the students create some question from the tittle of the text. Read, the teacher gave the material to read of the students. In the step of Reflect, the students thing about what they have just read by making connection and applyig the information. Recite, in this step the students commited the answer/information to generate the questions from what they have created the questions, and the students could the use of the heading or bold words the statement would the answer from the questions. Review this is the last steps, in this steps the teacher gave the instruction to the students to rereading the material and then write down the answer the question about their have read. The writer suggested make and teaching and learning process more interesting and enjoyable.

2. The other researches, it is suggested to develop the related and strategy to make better and may also conduct research on other genre of text to prove whether the use PQ4R strategy. It has been revealed that PQ4R strategy has significantly improved students' reading comprehension of narrative text. The other researchers can involve the students from different level such as senior $r$ high school since they have different character with the students in senior high school level. Thus, the other researchers who want to conduct similar research can use this thesis as their reference.

3. The students are suggested study more and active in teaching learning process using PQ4R strategy and the students should not be embarrassed to share their idea during the lesson. The students should read the material carefully, so they can make questions related to the material. By making questions will help the students understand the text. It will be very useful for increasing their knowledge in reading comprehension and always practice by using PQ4R strategy.

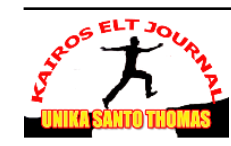




\section{BIBLIOGRAPHY}

Ahuja, Pramila. 2007. Communication Skills: How to Increase Your Reading Speed. New Delhi: Sterling Publisher.

Al, Talal. Abd.,\&Hameed, Al, Odwan. 2012. The Effect of The Directed Reading Thinking Activity through Cooperative Learning on English Secondary Stage Students' Reading Comprehension inJordan. International Journal Humanities and Social Science, 2(16).

Allen, Jannet. 2008. More Tools for Teaching Content Literacy. Virginia: Stenhouse.

Anderson, Mark, \& Anderson, Kathy. 1997. Text Types in English. Sidney: Macmilan Education Australia. PTY. LTD.

Ayres, Edward, L. 2008. Narrative Text. New York: Oxford University Press.

Best, John, N., \& Khan, James, V. 2002. Research in Education. New Delhi: Prentice Hall of India.

Bonner, Margaret. 1994.Step Into Writing. London: Longman.

Bower, Gordon. H. 1975. The Psychology of Learning and Motivation: Advances in Researh and Theory. New York: Academic Press.

Brown, Doughlas. 2003. Language Assessment Principle and Classroom Practices. Chicago: Longman.

Brunner, Judy. T. 2013.Doing What Works: Literacy Strategies for the Next Level. New York: Rowman \& Littlefield Publisher.Inc.

Burns, Anne. 1984. Teaching English In Today's Elementary Schools. Third edition. Boston : Houngthon Mifflin Company 2010. Doing Action Research in English Language Teaching: A Guide for Practitioners. New York: Routledge.

Cline, Frederick, et al. 2006. Focus Group Reactions to Three Definitions of Reading. Minneapolis, MN: National Accessible Reading Assessment Projects.

Gerot, Linda, \& Peter Wignel.1995. Making Sense of Functional Grammar. Sydney: Gerid Stabler.

Grabe,Wignel, \& Stoller, Fredricka. L. 2002. Teaching and Researching: Reading. Pearson Education.

Harley, Trevor. 2008. The Psychology of Language: From Data to Theory.New York: Psychology Press.

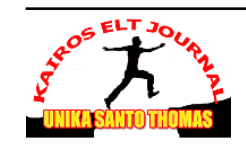


Kemmis, Stephen., \& McTaggart, R. 1998. The Action Research Planner (3rd Edition). Victoria: Deakin University Press.

Klingner, Janette. K., et al. 2007. Teaching Reading Comprehension to Students with Learning Difficulties. New York: The Guilford Press.

Larson, Mildred L. 1984.Meaning-based translation: A guide to cross-language equivalence. Lanham: University Press of America.

Manalu, Mediana. 2014. Improving Sudents' Achievement In Reading Comprehension Through Preview, Question, Read, Reflect, Recite, Review (PQ4R) Technique. A Thesis, Unpublished. State University of Medan.

Negari, et al. 2016. " The Effect of Jigsaw Task on Iranian EFL Learners' Reading Skill Improvement”. International Journal of Education Investigations. 3 (1), 10-19.

Permana, Tahan. D., \& Zuhri, F. 2013. The implementation of Pictures Series as Media in Teaching Writing of Narrative Text of the Tenth Grades of Senior high School. Journal of Retain, 1 (1), 1-8.

Rathus, Spencer, A. 2013. Psychology: Concept \& Connections. Nineth Edition. Belmont: Wads Worth Cengage Learning.

Robert, Tresa, A. 2017. Literacy Succes for Emergency Bilinguals: Getting it Right in the PreK-2 Classroom. New York: Teachers College Press.

Siahaan, Sanggam., Shinoda, Khisno. 2008.Generic Text Structure. Yogyakarta: Graha Ilmu.

Syafirah, Lailatis. 2015.The Application of PQ4R To Improve Students' Reading Comprehension. A Thesis, Unpublished. State Institute for Islamic Studies (IAIN) Salatiga.

Welsch, Kathryn, et.al. 2005. Metacognition in Literacy Learning: Theory, Assesment, Instruction and Professional Development. London: Lawrence Erlbaum Associates Publisher.

Westwood, Peter, S. 2008. What Teachers Need to Know About and Writing Difficulties. Victoria: Acer Press.

Winston, Rinehart. 2000. Introduction to Research in Education. Chicago: Longman 